\title{
PENGEMBANGAN MEDIA BERBASIS MULTIMEDIA INTERAKTIF UNTUK MENINGKATKAN PEMAHAMAN SISWA MAN 2 BATU MATERI KINGDOM ANIMALIA
}

\author{
Feni Nur'aini ${ }^{1}$, Lise Chamisijatin ${ }^{1}$, Nurwidodo ${ }^{1}$ \\ ${ }^{1}$ Pendidikan Biologi FKIP Universtias Muhammadiyah Malang, \\ e-mail : lise_chin@yahoo.com
}

\begin{abstract}
Learning biology plays an important role in the educational process as well as the development of technology, because biology has an effort for human to generate interest in science and technology development.Various issues that arise in school in biology learning materials associated with the Kingdom Animalia and the material is very much difficult for students to understand and time limitations in the learning process. So there should be used development of teaching media to overcome this. The purpose of this study are: (1) to know the effectiveness of the implementation of teaching media development, (2) to know the level of students understanding by using the application of teaching media development. This type of research is development research or Research and Development $(R \& D)$. the development used is based on the development steps from Borg \& Gall (1983) modified from Sukmadinata (2010) which includes three steps, namely: preliminary study, development and validation. To determine the effectiveness of the implementation of teaching media development is done by giving the questionnaire to students. To determine the level of students understanding performed pretest and posttest. The research was conducted on 28 March to 29 September 2013 at MAN 2 Batu Malang. The results of this development in the form of teaching media product Biology that has been through some trials and revisions of the experts and students. Based on the feasibility of media experts, subject matter experts, and students teaching media are stated that it is very viable and effective used in learning. Based on the experimental test on class treatment there was an increasing students' understanding of the material of the Kingdom Animalia that is the average value before using the media (pretest) increased from 41.60 to 90.3 after using the media (posttest), while the control class average value before reading textbooks (pretest) increased from 48.80 to 68.60 (posttest) after reading the textbooks. Thus it can be stated that teacing media based interaktive multimedia is more effective in improving students' understanding of $X$ class of MAN 2 Malang on the Kingdom Animalia subject.
\end{abstract}

Kata kunci: Animalia kingdom, learning of media, interactive multimedia

Biologi sebagai salah satu bidang IPA merupakan konsep pernbelajaran alam dan mempunyai hubungan yang sangat luas terkait dengan kehidupan manusia. Pembelajaran biologi sangat berperan dalam proses pendidikan dan juga perkembangan Teknologi, karena biologi memiliki upaya untuk membangkitkan minat manusia dalam rnengernbangkan ilmu pengetahuan dan teknologi serta pemahaman tentang alam semesta yang rnempunyai banyak fakta yang belum terungkap dan masih bersifat rahasia. Sehingga hasil penemuannya dapat dikernbangkan menjadi ilmu pengetahuan alam yang baru dan dapat diterapkan dalam kehidupan sehari-hari. Materi biologi memiliki cakupan yang luas mengenai bagaimana mengenal diri sendiri, mengenal makhluk hidup di sekitar, mengetahui hubungan makhluk hidup dengan makhluk hidup lain serta lingkungannya. Mata pelajaran Biologi dikembangkan melalui kemampuan berpikir analitis, induktif, dan deduktif untuk menyelesaikan masalah yang berkaitan dengan peristiwa alam sekitar. Penyelesaian masalah yang bersifat kualitatif dan kuantitatif dilakukan dengan 
menggunakan pemahaman dalam bidang fisika, kimia, biologi dan pengetahuan pendukung lainnya (Depdiknas, 2007). Salah satu materi biologi yang berkaitan dengan alam sekitar yaitu keanekaragaman hayati.

Kurikulum berbasis kompetensi telah dirumuskan sejak tahun 2004, dan terus disempurnakan oleh tim kerja. Namun kenyataannya di lapangan tidak semua sekolah mampu mencapai kompetensi sesuai dengan yang tertera di dalam kurikulum, meskipun ada sekolah yang mampu mencapai kualifikasi tinggi dengan kualitas siswa dan pengajarnya yang baik. Tentunya keberhasilan tersebut didukung dengan adanya fasilitas yang memadai. Berdasarkan Kuikulum Satuan Tingkat Pendidikan (KTSP) 2006 pada mata pelajaran biologi standar kompetensi yang harus dicapai oleh siswa pada materi keanekaragaman hayati tertuang pada standar kompetensi nomor 3 yaitu siswa mampu mengaplikasikan prinsip-prinsip pengelompokan makhluk hidup untuk mempelajari keanekaragaman dan peran keanekaragaman hayati bagi kehidupan.

Berdasarkan standar kompetensi nomer 3 tentang keanekaragaman hayati yang tertuang dalam KTSP 2006 terdapat beberapa kompetensi dasar yang harus dicapai dalam pembelajaran biologi, diantaranya yaitu a) Merumuskan konsep keanekaragaman hayati melalui kegiatan pengamatan terhadap lingkungan sekitarnya, b) Mengkomunikasikan wawasannya tentang keanekaragaman hayati di Indonesia, c) Mengklasifikasikan keanekaragaman hayati, d) Mendeskripsikan ciri-ciri Kingdom Monera dan mengkomunikasikan perannya dalam kehidupan, e) Menyajikan data hasil identifikasi Kingdom Protista berdasarkan ciri-ciri yang dapat diamati, f) Mendeskripsikan ciri-ciri Kingdom Fungi (jamur) berdasarkan struktur tubuh dan peranannya bagi kehidupan, g) Mendeskripsikan dan mengkomunikasikan ciri-ciri Kingdom Plantae dan peranannya bagi kehidupan, h) Mendeskripsikan dan mengkomunikasikan ciri-ciri Kingdom Animalia dan peranannya bagi kehidupan.

Berdasarkan hasil wawancara yang dilakukan oleh peneliti tanggal 28 Maret 2013 kepada guru biologi kelas X MAN 2 Malang, dapat disimpulkan bahwa kesulitan memahami materi kingdom animalia yang cukup banyak dengan media yang sangat terbatas, seperti buku pelajaran, LKS, gambar, dan lingkungan sekitar yang keberadaanya masih terpisah sehingga membuat siswa membutuhkan usaha keras dalam memahami materi tersebut. Selain itu guru juga mengakui bahwa penggunaan media yang terpisah membuat siswa hanya bergurau dalam melakukan pembelajaran, dikarenakan pemberian materi di dalam kelas sedangkan untuk mengetahui contoh hewan masih harus turun di lapang, hal tersebut yang membuat guru merasa kesulitan untuk membelajarkan materi kingdom animalia. Guru juga mengakui bahwa media yang digunakan selama ini kurang efektif, karena jumlah jam pelajaran yang sangat terbatas dan materi yang harus dipahami terlalu banyak. Adanya media pembelajaran yang dapat mempermudah guru dalam menyampaikan materi merupakan salah satu harapan guru dalam proses pembelajaran. Untuk mengatasi masalah diatas diperlukan suatu alternatif yang dapat dan mudah dijangkau dalam melakukan proses pembelajaran.

Alterntif untuk masalah ini yaitu penerapan e-learning pada proses pembelajaran. Menurut Munadi (2008) elearning dapat diartikan sebagai jenis belajar mengajar yang memungkinkan tersampaikannya bahan ajar ke siswa dengan menggunakan media internet atau media jaringan komputer lain. Dimana $e$ learning tersebut dikemas dalam multimedia interaktif. Multimedia dapat diartikan sebagai perpaduan dari berbgai media yang terdiri dari teks, grafis, gambar diam, animasi, suara, dan video untuk menyampaikan pesan kepada publik (Wahono, 2008). Sementara itu komputer mempunyai kemampuan untuk menyimpan, mengolah, dan menyajikan data secara 
cepat. Dalam bahasa pemograman tertentu, komputer dapat bernteraksi dengan user. Komputer seolah-olah dapat merespon setiap input data yang diberikan oleh user sehingga terjadi komunikasi timbal balik antara user dengan komputer. Oleh karena itu, jenis multimedia dapat dibedakan menjadi dua, yaitu multimedia linier dan multimedia interktif (Wahono, 2008). Multimedia linier adalah suatu multimedia yang tidak dilengkapi dengan alat pengontrol apapun yang dapat dioperasikan oleh pengguna. Multimedia ini berjalan sekuensial (berurutan), contohnya TV dan film. Sedangkan multimedia interaktif adalah suatu multimedia yang dilengkapi dengan alat pengontrol yang dapat dioperasikan oleh pengguna sehingga dapat memilih apa yang dikehendaki untuk proses berikutnya.contoh multimedi interaktif adalah multimedia pembelajaran interaktif, aplikasi, dan lain-lain (Anwar, 2007). Dengan kemudahan yang diberikan maka digunakan multimedia interaktif dalam proses belajar sebagai alat bantu mengajar.

\section{METODE}

Penelitian ini termasuk jenis penelitian pengembangan atau Research and Development (R\&D). Penelitian pengembangan adalah suatu proses atau langkah-langkah untuk mengembangkan suatu produk baru atau menyempurnakan produk yang telah ada yang dapat dipertanggungjawabkan (Sukmadinata, 2010). Model pengembangan yang akan digunakan dalam penelitian pengembangan ini adalah model pengembangan Borg and Gall. Adapun langkah-langkah penelitian dan pengembangan Borg \& Gall adalah sebagai berikut: 1) penelitian dan pengumpulan data, 2) perencanaan, 3) pengembangan draf produk, 4) uji coba lapangan awal, 5) merevisi hasil uji coba, 6) uji coba lapangan, 7) penyempurnaan produk hasil lapangan, 8) uji pelaksanaan lapangan, 9) penyempurnan produk akhir, 10) disemenasi dan implementasi (Sukmadinata, 2010). Langkah-langkah penelitian dan pengembangan Borg \& Gall dimodifikasi oleh Sukmadinata menjadi tiga tahap, yaitu: 1) studi pendahuluan, 2) pengembangan model, 3) uji model.

Secara prosedural langkah-langkah penelitian pengembangan Borg \& Gall yang dimodifikasi oleh Sukmadinata adalah studi pendahuluan, pengembangan, validasi (gambar 1).

\section{STUDI \\ PENGEMBANGAN \\ PENDAHULUAN \\ PENGUJIAN/ \\ VALIDASI}

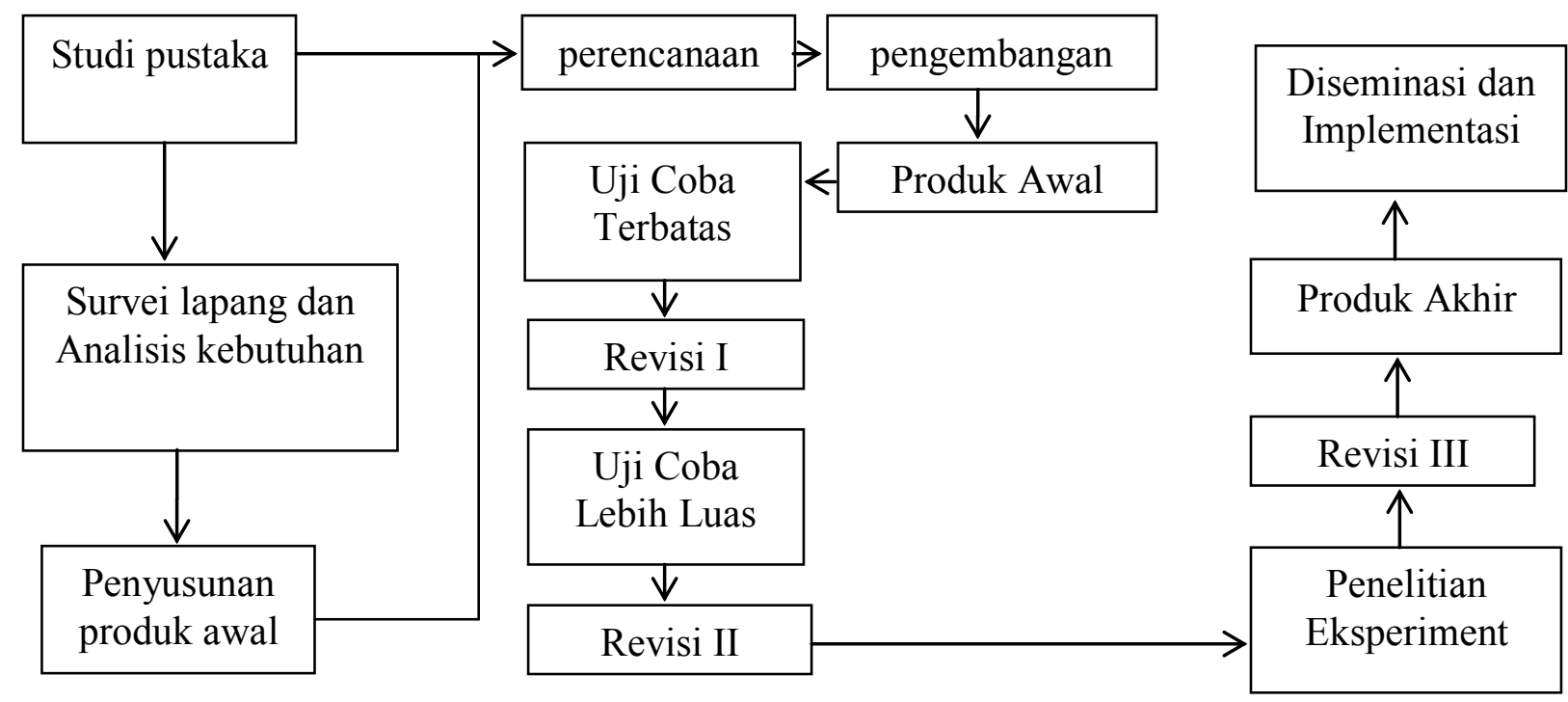

Gambar 1. Langkah-langkah penelitian pengembangan Borg and Gall (dimodifikasi oleh Sukmadinata, 2010) 
Pada tahap ini peneliti melakukan survei atau penelitian ke sekolah yang dituju yaitu MAN 2 Malang untuk mengumpulkan data tentang masalah yang dihadapi dalam proses belajar mengajar terkait dengan penggunaan media sebagai alat pendukung pembelajaran, kebutuhan siswa dalam pembelajaran, serta potensi yang dimiliki oleh sekolah.

Studi pustaka ini menentukan sistematika tiap-tiap filum pada materi kingdom animalia. Selain menentukan sistematika filum, pengembang juga melakukan studi pustaka tentang pengembangan media pembelajaran berbasis multimedia interaktif, serta mengkaji tentang penelitian terdahulu terkait dengan pengembangan media pembelajaran berbasis multimedia interaktif pada materi kingdom animalia dalam dunia pendidikan.

Produk yang dikembangkan berupa media pembelajaran, yaitu multimedia interaktif. Contoh dari multimedia interaktif yaitu multimedia pembelajaran intraktif, aplikasi game, dll. Contoh dari multimedia pembelajaran diantaranya adalah macromedia flash, adobe captivate, power point, kuis creator, dll. Pada pengembangan produk ini media yang akan dikembangkan berupa macromedia flash. Peneliti melakukan perancangan prototipe pada media tersebut. Dalam langkah perencanaan dan pengembangan produk awal ini ada dua hal yang harus diperhtikan dalam mengembangkan media, yaitu: (1) penentuan dan penyusunan naskah media dan (2) produksi media.

Uji coba produk yang dilakukan peneliti dalam pengembangan dimaksudkan untuk mengetahui kualitas produk sebagai media pembelajaran dan mengumpulkan data yang dapat dipakai untuk merevisi produk. Uji coba produk dilakukan sebanyak dua kali yaitu uji coba terbatas dan uji coba lebih luas.

Tahap uji coba produk pengembangan ini merupakan dilaksanakannya evaluasi formatif. Pada desain uji coba produk ini, dibagi menjadi tiga tahap, yaitu uji coba terbatas, uji coba lebih luas, dan penelitian eksperimen.

Uji coba terbatas dilakukan oleh ahli media dan ahli materi. Pengujian oleh ahli media bertujuan untuk memberikan penilaian dan saran mengenai tampilan media pembelajaran berbasis multimedia interktif. Pengujian oleh ahli materi bertujuan untuk mengevaluasi, apakah materi yang terdapat dalam media tersebut sudah sesuai dengan $\mathrm{SK} / \mathrm{KD}$ dan tujuan pembelajaran.

Uji coba yang kedua dilakukan pada lingkup lebih luas. Pada uji lebih luas ini siswa diminta mengisi angket penilian terhadap media yang ditayangkan. Uji coba lebih luas ini mengambil sampel sebanyak 20 siswa kelas X MAN Malang 2.

Subjek uji coba pada uji coba terbatas terdiri dari ahli media dan ahli materi. ahli media merupakan seseorng yang mengerti dan mahir tentang multimedia interaktif. Sedangkan ahli materi adalah seseorang yang ahli dalam konsep kingdom animalia. Subjek uji coba pada uji coba lebih luas adalah 20 siswa kelas X MAN 2 Malang. Setelah melakukan uji coba lebih luas dilakukan revisi produk dengan berpedoman terhadap hasil angket yang diedarkan kepada siswa sebelum dilakukan penelitian eksperimen.

Penelitian eksperimen merupakan tahap pengujian keampuhan dari produk yang dihasilkan. Pengujian dilakukan dengan menggunakan metode eksperimen. Eksperimen yang digunakan tergolong quasi eksperimenal. Bentuk 
desain quasi eksperimen yang digunakan yaitu nonequivalent control group desaign. Desain penelitian ini dapat digambarkan sebagai berikut:

$\mathrm{O}_{1}$ dan $\mathrm{O}_{3}$ : Tingkat pemahaman siswa sebelum diberi perlakuan media

$\mathrm{O}_{2} \quad$ : Tingkat pemahaman siswa setelah diberi perlakuan media

$\mathrm{O}_{4} \quad$ : Tingkat pemahaman siswa tidak diberi perlakuan media

Pada penelitian eksperimen ini peneliti menggunakan sampel sebanyak 2 kelas, yaitu siswa kelas X-6 dan X-8 MAN Malang 2 Batu yang dijadikan dalam satu kelompok. Satu kelompok tersebut akan dipisah menjadi dua setengah diberi perlakuan dan setengah tidak diberi perlakuan.

Berdasarkan hasil penelitian eksperimen, maka peneliti melakukan revisi akhir atau penyempurnaan produk yang berupa multimedia interaktif. Setelah tahap revisi produk akhir telah selesai maka akan dihasilkan media pembelajaran yang berupa multimedia interaktif yang siap dan layak digunakan dalam proses pembelajaran.

Dieseminasi dan implementasi dari produk yang dikembangkan membutuhkan sosialissi yang cukup panjang dan lama serta membutuhkan biaya yang cukup mahal. Oleh karena itu penelitian dan pengembangan ini hanya sampai pada tahap pembuatan produk akhir. Sehingga tahap diseminasi dan implementasi diusulkan untuk dilakukan penelitian selanjutnya.

Data yang diperoleh dalam penelitian pengembangan media interaktif ini terdiri dari data kualitatif dan kuantitatif. Data kualitatif diperoleh dari kritikan Sdan saran perbaikan dari ahli media, ahli materi dan siswa. Sedangkan data kuantitatif diperoleh dari penilaian ahli media dan ahli materi pada saat uji coba terbatas dan penilaian dari siswa pada saat uji coba lebih luas melalui angket yang berisi pilihan angka/skala terhadap kualitas dan efektivitas multimedia interaktif. Instrumen pengumpulan data dilakukan dengan berbagai metode. Diantaranya adalah wawancara, angket, dan metod tes.

Teknik analisa data menggunakan analisis deskriptif kualitatif dan kuantitatif. Analisa data kualitatif digunakan untuk mengolah data hasil wawancara pada guru serta komentar dari para ahli media dan ahli materi. Teknik analisis data data kuantitatif berupa skor angket penilaian untuk ahli materi dan ahli media adalah dengan menghitung prosemtase dari butir-butir petanyaan pada angket tersebut. Rumus yang digunakan untuk menghitung data dari ahli materi biologi yaitu guru biologi, ahli media, dan responden adalah rumus menurut arikunto (2006) sebagai berikut:

a. Rumus untuk mengolah prosentase per item

$$
\mathrm{P}=\frac{\sum \mathrm{x}}{\sum \mathrm{x} i} \mathrm{x} 100 \%
$$

Keterangan:

$\mathrm{P}=$ Persentase

$\sum \mathrm{x}=$ jumlah nilai jawaban

responden dalam setiap item

$\sum \mathrm{x} i=$ jumlah skor ideal dalam

satu item

b. Rumus untuk mengolah

prosentase data secara

keseluruhan

$$
\mathrm{P}=\frac{\sum \mathrm{x}}{\sum \mathrm{x} i} \mathrm{x} 100 \%
$$

Keterangan:

$\mathrm{P}=$ Persentase

$\sum \mathrm{x}=$ jumlah nilai jawaban

responden dalam seluruh item

$\sum \mathrm{x} i=$ jumlah skor ideal dalam

keseluruhan item

Berdasarkan penghitungan dengan menggunakan persamaan diatas ditentukan kriteria kevalidan data angket penilaian validator materi dan media (Tabel 1). 
Untuk mengetahui keefektifan penggunaan media dalam meningkatkan hasil belajar, maka penghitungan data nilai pretest dan postest siswa dinalisis menggunakan: 1) deskriptif prosentase untuk mengetahui perolehan hasil menjawab pertanyaan sebelum dan sesudah diberikan materi tentang kingdom animalia melalui pemutaran multimedia interaktif, 2) uji t untuk mengetahui perbedaan antara hasil pretest dan postest.

Tabel 1. Kriteria Kevalidan

\begin{tabular}{lll}
\hline \multicolumn{1}{c}{ Tingkat Kevalidan } & \multicolumn{1}{c}{ Kriteria } & \multicolumn{1}{c}{ Keterangan } \\
\hline $\mathbf{7 6 \% - 1 0 0 \%}$ & Sangat layak & Sangan Valid, Tidak direvisi \\
$\mathbf{5 6 \% - 7 5 \%}$ & Layak & Valid, Tidak direvisi \\
$\mathbf{4 0 \% - 5 5 \%}$ & Kurang layak & Kurang Valid, Revisi \\
Kurang dari 40\% & Tidak layak & Tidak Valid, Revisi \\
\hline
\end{tabular}

Uji t dilakukan dengan menggunakan analisis paired dengan menggunakan penghitungan melalui software IBM statistsic SPSS 21.

Untuk mengetahui keefektifan penggunaan media dalam meningkatkan hasil belajar, maka penghitungan data nilai pretest dan postest siswa dinalisis menggunakan: 1) deskriptif prosentase untuk mengetahui perolehan hasil menjawab pertanyaan sebelum dan sesudah diberikan materi tentang kingdom animalia melalui pemutaran multimedia interaktif, 2) uji t untuk mengetahui perbedaan antara hasil pretest dan postest. Uji $t$ dilakukan dengan menggunakan analisis paired dengan menggunakan penghitungan melalui software IBM statistsic SPSS 21.

\section{HASIL DAN PEMBAHASAN}

Hasil dari survei lapang dan analisis kebutuhan peneliti mendapatkan keterangan dari guru melalui rekaman wawancara. Dapat saya simpulkan dari rekaman wawancara bahwa masalah yang dihadapi guru dalam membelajarkan materi kingdom animalia kepada siswa yaitu guru kesulitan mebelajarkan materi kingdom animalia dikarenakan materi yang sangat banyak, waktu yang relatif sedikit, dan media yang kurang memadai. Ketika guru menyuruh siswa untuk membawa contoh hewannya hanya sedikit siswa yang membawanya dan kebanyakan siswa sering menakut-nakuti siswa yang lain dengan hewan yang sedikit menjijikkan. Selain itu fasilitas pendukung pengembangan media telah ada disekolah meskipun tidak semua ada di ruang kelas, seperti layar LCD. Setelah melakukan wawancara dan mengetahui permasalahan yang dihadapi oleh guru, peneliti melakukan tahap selanjutnya yaitu need assessment. Dimana need assessment dilakukan dengan tujuan dapat mengetahui kebutuhan yang diperlukan siswa dalam pembelajaran biologi khususnya pada materi kingdom animalia. Adapun hasil dari need assessment meliputi ciri-ciri invertebrata dan vertebrata, klasifikasi invertebrata dan vertebrata, dan peran dari invertebrata dan vertebrata.

Adapun klasifikasi dari invertebrata meliputi ciri-ciri umum dari setiap filum pada invertebrata, kelas dari setiap filum pada invertebrata, dan peranan dari setiap filum pada invertebrata. Sedangkan untuk kalsifikasi vertebrata meliputi ciri-ciri umum dari setiap klas vertebrata, dan peranan dari setiap kelas pada vertebrata. Setelah didaatkan hasil need assesment maka selanjutnya dilakuan studi pustaka mengenai materi hasil dari need assesment.

Perencanaan dan pengembangan produk menghasilkan sebuah produk 
media pembelajaran biologi berbasis multimedia interaktif. Setelah dihasilkan media pembelajaran biologi berbasis multimedia interaktif, maka media tersebut divalidasi oleh ahli materi (Tabel 2) dan ahli media (Tabel 3). Setelah dilakukan penilaian produk awal maka dilakukan perbaikan/revisi media berdasarkan saran dari ahli materi. Setelah dilakukan perbaikan maka multimedia interaktif dinilai kembali oleh ahli materi. Adapun hasil penilaian ahli materi setelah revisi terdapat di Tabel 4.

Berdasarkan Tabel 4 dapat disimpulkan bahwa penilaian ahli materi terhadap materi yang disajikan dalam multimedia interaktif mengalami peningkatan prosentase dengan kualifikasi sangat layak, sehingga tidak perlu lagi dilakukan revisi/perbaikan konten materi dalam multimedia interaktif. Adapun perbandingan hasil penilaian ahli materi terhadap multimedia interaktif dapat dilihat pada grafik perbandingan (gambar 2).

Setelah dilakukan penilaian oleh ahli materi dan dinyatakan sangat valid, maka tahap selanjutnya adalah validasi media (Tabel 5). Berdasarkan Tabel 5 yang merupakan hasil penilaian/validasi oleh ahli media, maka masih perlu dilakukan perbaikan/revisi media supaya mendapatkan multimedia interaktif yang sangat maksimal sesuai dengan komentar dan saran dari ahli media (Tabel 6). Setelah dilakukan revisi, media yang sudah direvisi dinilai kembali oleh ahli media (Tabel 7).

Berdasarkan Tabel 6 dan 7 tentang penilaian multimedia interaktif sebelum dan sesudah revisi oleh ahli media dapat disimpulkan bahwa ada peningkatan prosentase yang menunjukkan bahwa tingkat kualifikasi juga tinggi. Sehingga sudah tidak perlu dilakukan revisi lagi. Karena kualifikasi penilain sudah menyatakan sangat layak dan sangat valid untuk digunakan sebagai sumber belajar. Adapun perbandingan hasil penilaian sebelum revisi dan sesudah revisi dapat dilihat pada gambar 3. Setelah dinyatakan sangat valid dengan kualifikasi sangat layak maka tahap selanjutnya dilakukan uji coba lebih luas kepada 20 orang siswa kelas X MAN 2 Malang Kota Batu (gambar 4).

Tabel 2. Hasil Penilaian Ahli Materi Terhadap Produk Awal Media

\begin{tabular}{|c|c|c|c|c|}
\hline No. & Aspek yang Dinilai & Persentase (\%) & Kualifikasi & Keterangan \\
\hline 1. & Tujuan & 75 & Layak & $\begin{array}{l}\text { Vaild, Tidak } \\
\text { Revisi }\end{array}$ \\
\hline 2. & Kebenaran konsep & 94 & Sangat Layak & $\begin{array}{c}\text { Sangat Valid, } \\
\text { Tidak Revisi }\end{array}$ \\
\hline 3. & $\begin{array}{c}\text { Bahan penarik } \\
\text { perhatian }\end{array}$ & 78 & Sangat Layak & $\begin{array}{l}\text { Sangat Valid, } \\
\text { Tidak Revisi }\end{array}$ \\
\hline 4. & Organisasi materi & 75 & Layak & $\begin{array}{c}\text { Vaild, Tidak } \\
\text { Revisi }\end{array}$ \\
\hline 5. & Sumber belasjar & 68 & Layak & $\begin{array}{l}\text { Vaild, Tidak } \\
\text { Revisi }\end{array}$ \\
\hline 6. & Evaluasi & 70 & Layak & $\begin{array}{c}\text { Vaild, Tidak } \\
\text { Revisi }\end{array}$ \\
\hline
\end{tabular}


Tabel 3. Komentar dan Saran Perbaikan Ahli Materi

\begin{tabular}{|c|c|c|}
\hline No. & Aspek yang Dinilai & Komentar dan Saran Ahli Materi \\
\hline 1. & Tujuan & - \\
\hline 2. & Materi & $\begin{array}{c}\text { Harus ada petunjuk melakukan praktikum tentang } \\
\text { golongan vertebrata dan invertebrata beserata suara, } \\
\text { menambahkan perkembangbiakan beberapa spesies } \\
\text { dari filum nematelminthes. }\end{array}$ \\
\hline 3. & Bahan penarik perhatian & $\begin{array}{c}\text { Tidak ada bahasa lisan. Bahasa lisan pada petunjuk } \\
\text { praktikum dijelaskan secara detail }\end{array}$ \\
\hline 4. & Organisasi Materi & - \\
\hline 5. & Sumber belajar & $\begin{array}{l}\text { Untuk panduan praktikum disertakan bagi setiap } \\
\text { phylum secara singkat dan detail }\end{array}$ \\
\hline 6. & Evaluasi & $\begin{array}{l}\text { Untuk petunjuk pretest/pascatest dan petunjuk } \\
\text { praktikum dijelaskan secara singkat dan jelas. }\end{array}$ \\
\hline
\end{tabular}

Tabel 4. Data Hasil Penilaian Ahli Materi sesudah Revisi

\begin{tabular}{ccccc}
\hline No. & Aspek yang Dinilai & Persentase (\%) & Kualifikasi & Keterangan \\
\hline 1. & Tujuan & 100 & Sangat Layak & $\begin{array}{c}\text { Sangat Valid, Tidak } \\
\text { Revisi }\end{array}$ \\
2. & Kebenaran konsep & 97 & Sangat Layak & $\begin{array}{c}\text { Sangat Valid, Tidak } \\
\text { Revisi }\end{array}$ \\
3. & $\begin{array}{c}\text { Bahan penarik } \\
\text { perhatian }\end{array}$ & 93 & Sangat Layak & $\begin{array}{c}\text { Sangat Valid, Tidak } \\
\text { Revisi }\end{array}$ \\
4. & $\begin{array}{c}\text { Organisasi materi } \\
\text { 5. }\end{array}$ & 100 & Sangat Layak & $\begin{array}{c}\text { Sangat Valid, Tidak } \\
\text { Revisi }\end{array}$ \\
6. & Sumber belajar & 94 & Sangat Layak & $\begin{array}{c}\text { Sangat Valid, Tidak } \\
\text { Revisi }\end{array}$ \\
\hline
\end{tabular}

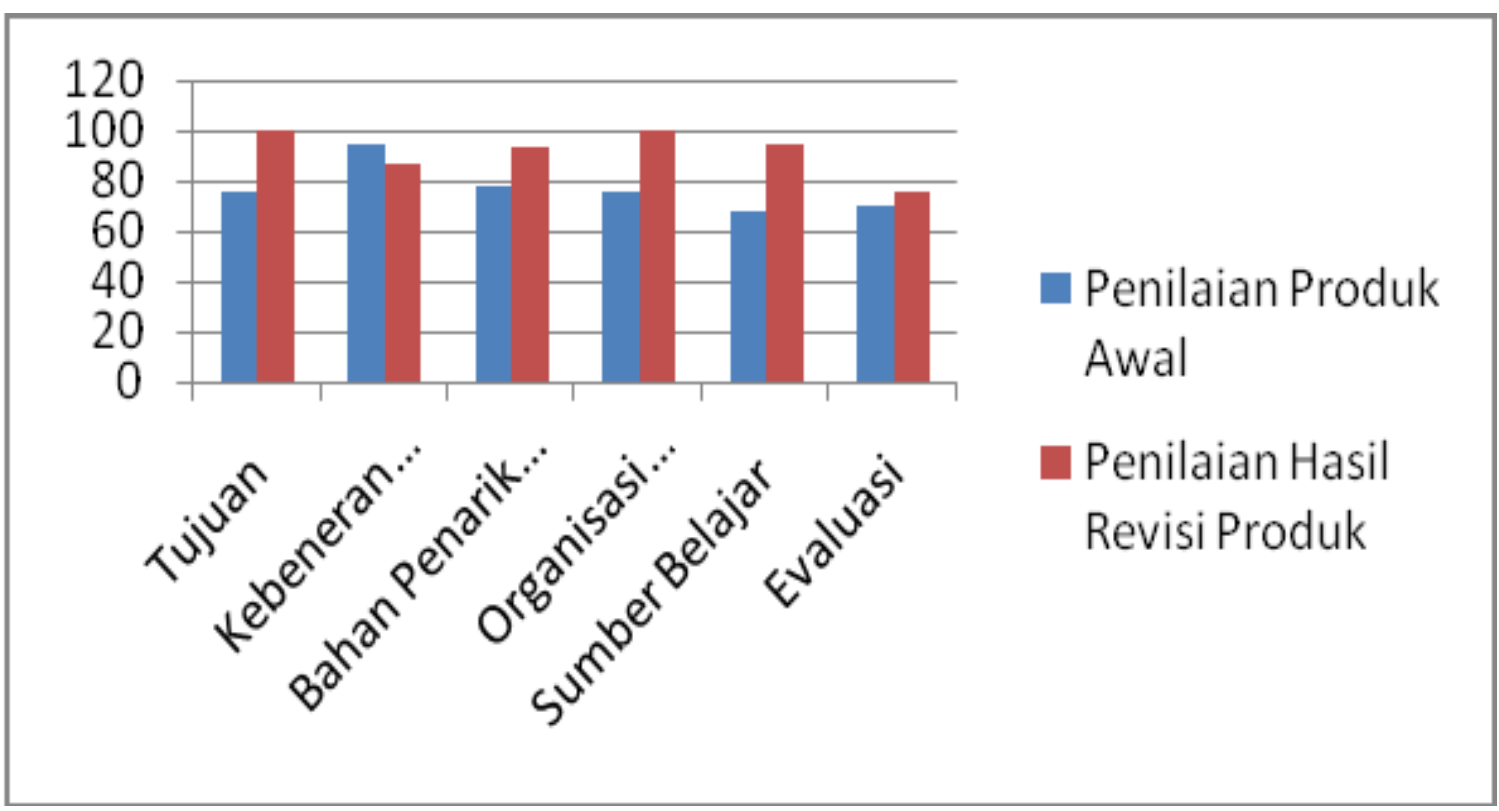

Gambar 2. Grafik perbandingan hasil penilaian produk awal dan revisi produk oleh ahli materi 
Tabel 5. Data Hasil Penilaian Ahli Media Sebelum Revisi

\begin{tabular}{|c|c|c|c|c|}
\hline No. & Aspek yang Dinilai & Persentase (\%) & Kualifikasi & Keterangan \\
\hline 1. & Efektifitas & 79 & Sangat Layak & $\begin{array}{l}\text { Sangat Valid, } \\
\text { Tidak Revisi }\end{array}$ \\
\hline 2. & Animasi & 69 & Layak & $\begin{array}{l}\text { Valid, Tidak } \\
\text { Revisi }\end{array}$ \\
\hline 3. & Teks & 83 & Sangat Layak & $\begin{array}{l}\text { Sangat Valid, } \\
\text { Tidak Revisi }\end{array}$ \\
\hline 4. & Audio & 75 & Layak & $\begin{array}{l}\text { Valid, Tidak } \\
\text { Revisi }\end{array}$ \\
\hline 5. & Fasilitas & 88 & Sangat Layak & $\begin{array}{l}\text { Sangat Valid, } \\
\text { Tidak Revisi }\end{array}$ \\
\hline 6. & $\begin{array}{l}\text { Integrasi seluruh aspek } \\
\text { dalam media }\end{array}$ & 50 & Kurang Layak & $\begin{array}{c}\text { Kurang Valid, } \\
\text { Revisi }\end{array}$ \\
\hline 7. & $\begin{array}{c}\text { Penilaian media secara } \\
\text { keseluruhan }\end{array}$ & 75 & Layak & $\begin{array}{l}\text { Valid, Tidak } \\
\text { Revisi }\end{array}$ \\
\hline
\end{tabular}

Tabel 6. Komentar dan Saran Perbaikan Ahli Media

\begin{tabular}{|c|c|c|}
\hline No. & Aspek yang Dinilai & Komentar dan Saran Ahli Media \\
\hline 1. & Efektifitas & $\begin{array}{c}\text { Lengkapi dengan video dan animasi yang } \\
\text { menggambarkan konsep-konsep penting dan buat } \\
\text { sajian dalam bentuk sequencing (satu persatu) }\end{array}$ \\
\hline 2. & Animasi & $\begin{array}{l}\text { Banyak gambar yang terlalu kecil sehingga sulit untuk } \\
\text { dibaca. Sajikan gambar dalam bentuk sequencing atau } \\
\text { tahap demi tahap. Baca lampiran hasil review saya }\end{array}$ \\
\hline 3. & Teks & 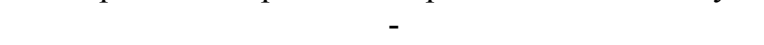 \\
\hline 4. & Audio & - \\
\hline 5. & Fasilitas & - \\
\hline 6. & $\begin{array}{l}\text { Integrasi seluruh aspek dalam } \\
\text { media }\end{array}$ & $\begin{array}{l}\text { Sebaiknya animasi yang ditampilkan adalah animasi } \\
\text { untuk menggambarkan konsep materi, bukan asesoris } \\
\text { media (missal intro dll) }\end{array}$ \\
\hline 7. & $\begin{array}{l}\text { Penilaian media secara } \\
\text { keseluruhan }\end{array}$ & $\begin{array}{l}\text { Lebih memahami hasil revie ahli media untuk saran } \\
\text { perbaikan }\end{array}$ \\
\hline
\end{tabular}

Tabel 7. Data Hasil Penilaian Ahli Media sesudah Revisi

\begin{tabular}{|c|c|c|c|c|}
\hline No. & Aspek yang Dinilai & Persentase (\%) & Kualifikasi & Keterangan \\
\hline 1. & Efektifitas & 96 & Sangat Layak & $\begin{array}{l}\text { Sangat Valid, Tidak } \\
\text { Revisi }\end{array}$ \\
\hline 2. & Animasi & 100 & Sangat Layak & $\begin{array}{l}\text { Sangat Valid, Tidak } \\
\text { Revisi }\end{array}$ \\
\hline 3. & Teks & 92 & Sangat Layak & $\begin{array}{l}\text { Sangat Valid, Tidak } \\
\text { Revisi }\end{array}$ \\
\hline 4. & Audio & 100 & Sangat Layak & $\begin{array}{l}\text { Sangat Valid, Tidak } \\
\text { Revisi }\end{array}$ \\
\hline 5. & Fasilitas & 100 & Sangat Layak & $\begin{array}{l}\text { Sangat Valid, Tidak } \\
\text { Revisi }\end{array}$ \\
\hline 6. & $\begin{array}{l}\text { Integrasi seluruh aspek } \\
\text { dalam media }\end{array}$ & 100 & Sangat Layak & $\begin{array}{l}\text { Sangat Valid, } \\
\text { Revisi }\end{array}$ \\
\hline 7. & $\begin{array}{l}\text { Penilaian media secara } \\
\text { keseluruhan }\end{array}$ & 100 & Sangat Layak & $\begin{array}{l}\text { Sangat, Tidak } \\
\text { Revisi }\end{array}$ \\
\hline
\end{tabular}




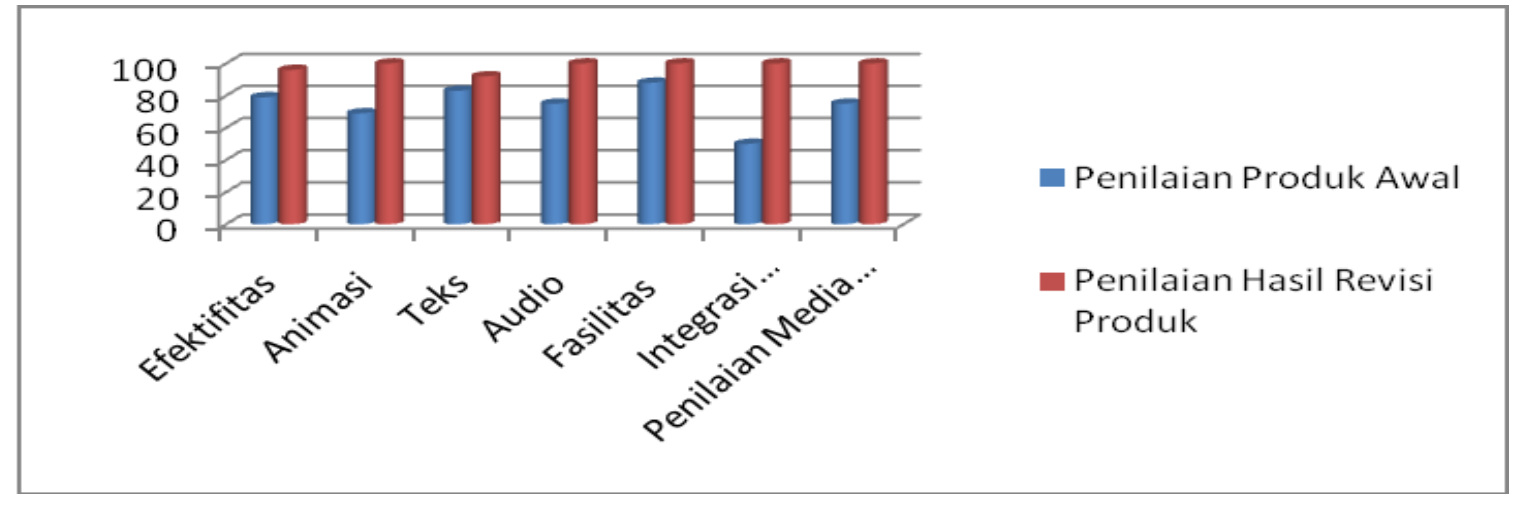

Gambar 3. Grafik perbandingan hasil penilaian produk awal dan revisi produk oleh ahli media

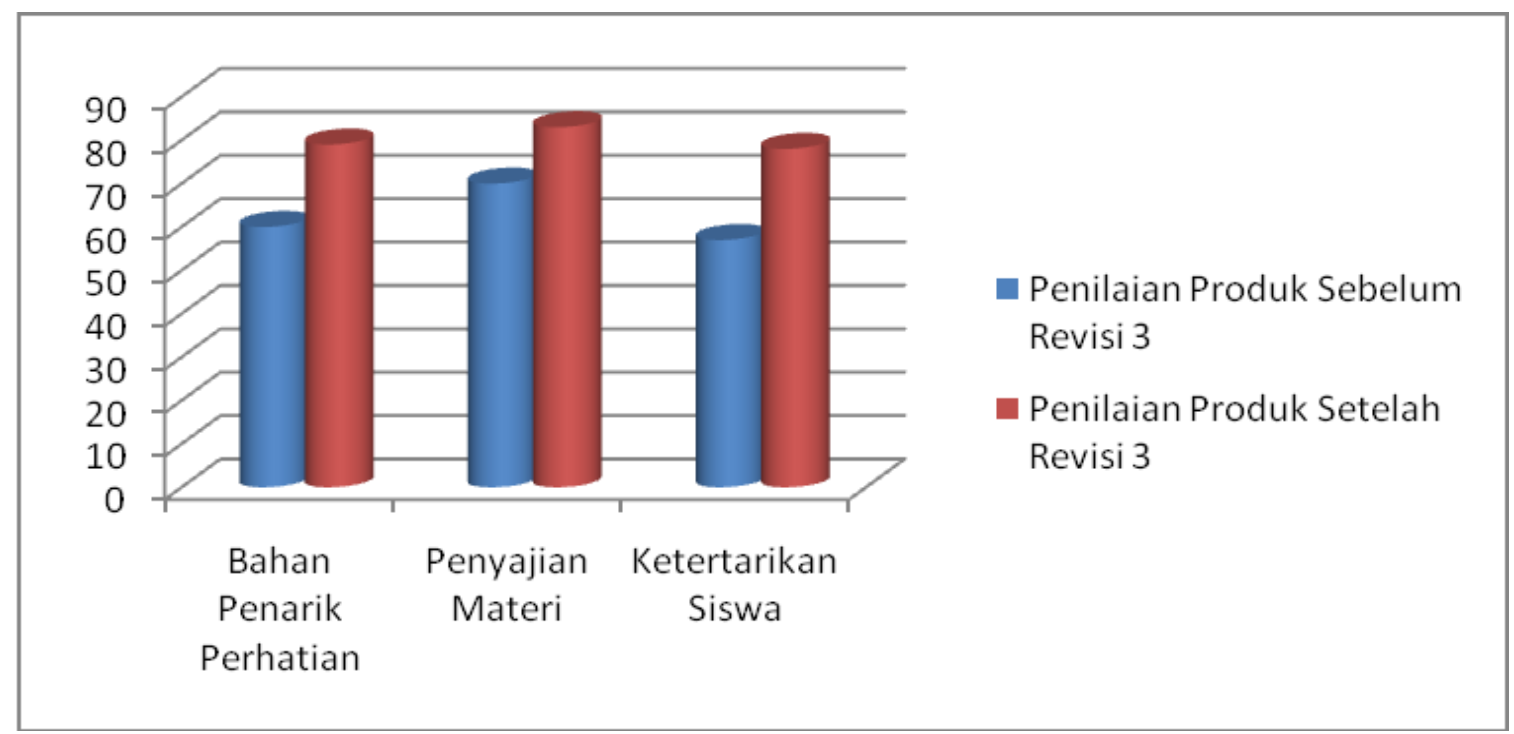

Gambar 4. Grafik perbandingan hasil penilaian produk multimedia interaktif oleh siswa pada uji coba lebih luas

Penilaian siswa terhadap multimedia interaktif pada uji coba lebih luas berturut-turut sebagai berikut: pada aspek penilaian bahan penarik perhatian $79 \%$ dengan kualifikasi sangat layak, aspek penilaian penyajian materi $83 \%$ dengan kualifikasi sangat layak, dan aspek penilaian ketertarikan siswa $78 \%$ dengan kualifikasi sangat layak. Berdasarkan hasil penilaian siswa pada beberapa aspek penilaian maka dapat disimpulkan bahwa media pembelajaran biologi berbasis multimedia interaktif ini sangat layak digunakan dalam pembelajaran.
Untuk menguji keefektifannya multimedia interaktif meningkatkan hasil belajar secara nyata, maka dilakukan uji eksperimen. Uji eksperimen ini menggunakan dua kelas, yaitu kelas kontrol dan keas perlakuan. Pada kelas kontrol siswa hanya diminta membaca buku teks pelajaran setelah diberi pretest. Setelah membaca buku teks pelajaran siswa diberikan postest dengan soal yang sama. Subjek untuk kelas kontrol yaitu kelas X-8 sebanyak 30 orang. Sedangkan untuk kelas perlakukan, awalnya siswa diberikan pretest kemudian di diberikan materi menggunakan multimedia 
pembelajaran interaktif yang dikembangkan. Setelah diberikan materi lewat penayangan multimedia pembelajaran siswa diberikan pretest. Berdasarkan hasil analisis paired sampel $\mathrm{t}$ test dengan menggunakan transform SPSS IBM 21 diperoleh hasil probabilitas (P) pada kelas perlakuan 0,000. Karena nilai $\mathrm{P}<0,05$ maka $\mathrm{H} 0$ ditolak. Rata-rata nilai sebelum menggunakan media pembelajaran berbasis multimedia interaktif \& sesudah menggunakan media pembelajaran berbasis multimedia interaktif adalah berbeda. Perolehan nilai pretest dan postest menunjukkan bahwa terjadi peningkatan skor siswa dan diperoleh rata-rata nilai sebelum menggunakan media (pretest) 41,60 mengalami peningkatan setelah menggunakan media (postest) 90,3. Dengan demikian dapat dinyatakan bahwa: (1) penggunaan media pembelajaran berbasis multimedia interaktif dapat meningkatakan pemaham siswa kelas X-6 pada materi kingdom animalia, (2) media pembelajaran yang dikembangkan sudah memenuhi SK/KD yang telah ditetapkan, karena siswa dapat menjawab soal pretest dan soal postest, (3) media pembelajaran yang dikembangkan dapat dijadikan media alternatif pada proses pembelajaran disekolah pada materi kingdom animalia karena media pembelajaran ini sudah dinyatakan sangat valid dan sangat layak digunakan sebagai media pembelajaran oleh ahli media.

Pada kelas kontrol diperoleh nilai probabilitas (P) 0,000. Karena nilai $\mathrm{P}<$ 0,05 maka H0 ditolak, rata-rata nilai pretest dan postest pada kelas kontrol juga berbeda. Berdasarkan perolehan nilai pretest dan postest terjadi peningkatan antara nilai pretest dan postest pada kelas kontrol. Namun perbedaan nilai pretest dan postest pada kelas kontrol tidak terlalu jauh dibandingkan dengan kelas perlakuan.
Perolehan rata-rata nilai sebelum membaca buku teks pelajaran (pretest) 48,80 dan rata-rata nilai setelah membaca buku teks pelajaran 68,60. Dengan demikian dapat dinyatakan bahwa penggunaan media pembelajaran berbasis multimedia interaktif dapat meningkatkan pemahaman siswa dan lebih efektif dalam materi kingdom animalia daripada membaca buku teks pelajaran.

\section{KESIMPULAN DAN SARAN}

\section{Kesimpulan}

1. Media pembelajaran yang dikembangkan sangat layak digunakan dalam proses pembelajaran, hal ini berdasarkan pada hasil penilaian ahli media terhadap aspek efektifitas, animasi, teks, audio, dan fasilitas pendukung yang ada pada multimedia interaktif dan ahli materi terhadap aspek tujuan, kebenaran konsep, bahan penarik perhatian, organisasi materi, sumber belajar, dan evaluasi.

2. Media pembelajaran yang dikembangkan sangat efektif digunakan dalam pembelajaran, hal ini berdasarkan pada hasil penilaian ahli media terhadap aspek efektivitas dan siswa terhadap aspek bahan penarik perhatian, penyajian materi dan ketertarikan siswa yang terdapat pada angket siswa pada saat uji coba lebih luas.

3. Media pembelajaran yang dikembangkan dapat meningkatkan pemahaman siswa pada materi Kingdom Animalia, hal ini berdasarkan pada uji coba eksperimen. Pada kelas perlakuan skor pemahaman siswa sebelum menggunaka multimedia interaktif dengan rata-rata 41,60 meningkat menjadi 90,3 setelah menggunakan multimedia interaktif. Sedangkan pada kelas kontrol skor pemahaman siswa sebelum membaca buku teks pelajaran dengan rata-rata 
48,80 menjadi 68,60 setelah membaca buku teks pelajaran. Dari hasil uji eksperimen dapat dikatakan bahwa penggunaan media pembelajaran berbasis multimedia interaktif lebih efektif meningkatkan pemahaman siswa dibandingkan dengan menggunakan buku teks pelajaran.

\section{Saran}

1. Multimedia interaktif yang dikembangkan hanya sampai pada tahap uji eksperimen. Diharapkan pengembang berikutnya lebih bisa mengembangkan multimedia interaktif ini pada tahap diseminasi dan implementasi.

2. Multimedia interaktif yang dikembangkan hanya terbatas pada materi Kingdom Animalia, diharapkan semua guru biologi memakai multimedia interaktif sebagai media pembelajaran pada materi lain, karena media ini dapat membuat proses pembelajaran lebih efektif. Terlebih lagi pada semua mata pelajaran.

\section{DAFTAR PUSTAKA}

Anwar, Khairil. 2007. Pembelajaran Bidang Studi Pendidikan Agama Islam Berbasis Multimedia Di SMP 18. Skripsi, Jurusan Tarbiyah Fakultas Agama Islam Univeritas Muhammadiyah Malang.

Depdiknas. 2007. Materi Soialisasi Kurikulum dan Pelatihan Tingkat Satuan Pendidikan. Jakarta: Direktorat Jenderal Pendidikan Dasar dan Menengah

Munadi, Yudhi. 2008. Media Pembelajaran Sebuah Pendekatan Baru. Jakarta: Gaung Persada Press

Sukmadinata, N. S. 2010. Metode Penelitian Pendidikan. Jakarta: PT Remaja Rosdakarya

Sutopo, Ariesto Hadi. 2002. Animasi dengan Macro Media Flash Berikut Action Script. Jakarta: Salemba Infotek 